FILONENKO Olena - Candidate of Science in Pedagogics, Associate Professor at Pedagogics, Primary Education and Educational Management Department, Nizhyn Mykola Gogol State University, 2, Grafska str., Nizhyn, 16602, Ukraine

ORCID: https://orcid.org/0000-0002-1036-2158

SAMOILENKO Olena - Candidate of Science in Pedagogics, Associate Professor at Pedagogics, Primary Education and Educational Management Department, Nizhyn Mykola Gogol State University, 2, Grafska str., Nizhyn, 16602, Ukraine

ORCID: http://orcid/0000-0002-2622-3064

DEMCHENKO Nataliia - Candidate of Science in Pedagogics, Associate Professor at Pedagogics, Primary Education and Educational Management Department, Nizhyn Mykola Gogol State University, 2, Grafska str., Nizhyn, 16602, Ukraine

ORCID: https://orcid.org/0000-0003-1382-0756

DOI: https://doi.org/10.24919/2413-2039.12/44.32

To cite this article: Filonenko, O., Samoilenko, O., Demchenko, N. (2021) Monitorynh problem orhanizatsii ta provedennia pedahohichnoi praktyky studentiv universytetu [Monitoring of problems of organization and conduct of pedagogical practice of university students]. Human Studies. Series of Pedagogy, 12 (44), 207-213, doi: https://doi.org/10.24919/2413-2039.12/44.32

\title{
MONITORING OF PROBLEMS OF ORGANIZATION AND CONDUCT OF PEDAGOGICAL PRACTICE OF UNIVERSITY STUDENTS
}

Summary. The authors present the importance of monitoring the state of pedagogical practice as an integral part of the system of future teacher training, as the study of factors that affect the quality of pedagogical practice provides objective information about the real situation, problems and ways to improve practical training. The authors consider the quality of organization and conduct of student practice as one of the priorities of the university, determine the types of pedagogical practice, characterize the stages of its implementation at Nizhyn Mykola Gogol State University.

The authors analyzed the research on the problem of improving pedagogical practice. It is noted that researchers focus on intensifying the interaction between higher and secondary education institutions in the process of organizing and conducting pedagogical practice of students, exercising systematic control over the process and results, its development of integration mechanisms that ensure effective interaction of higher education with employers.

The article presents the results of the study of the state of practical training of students, carried out by the Center Accreditation and Licensing of Educational Activities, Monitoring the Educational Quality at Nizhyn Mykola Gogol State University. Monitoring of the effectiveness of pedagogical practices shows us the proper level of their passage by students and provides an opportunity to outline the priority tasks as an important educational stage in the formation of a qualified teacher. The authors note that the main task is to improve the curriculum in terms of practical training and identify of the main positions that need to be changed: the content and forms of introductory practice; number of tasks and volumes and forms of reporting; guidance from university teachers.

Key words: pedagogical practice, preparation of the future teacher, monitoring of efficiency of pedagogical practices.

ФІЛОНЕНКО Олена - кандидат педагогічних наук, дочент кафедри педагогіки, початкової освіти та освітнього менеджменту, Ніжинський державний університет імені Миколи Гоголя, вул. Графська, 2, м. Ніжсин, 16602, Украӥна

ORCID: https://orcid.org/0000-0002-1036-2158

САМОЙЛЕНКО Олена - кандидат педагогічних наук, доцент кафедри педагогіки, початкової освіти та освітнього менеджменту, Ніжинський державний університет імені Миколи Гоголя, вул. Графська, 2, м. Ніжин, 16602, Украӥна

ORCID: http://orcid/0000-0002-2622-3064 
ДЕМЧЕНКО Наталія - кандидат педагогічних наук, доиент кафедри педагогіки, початкової освіти та освітнього менеджсенту, Ніжинський державний університет імені Миколи Гоголя, вул. Графська, 2, м. Ніжин, 16602, Україна

ORCID: https://orcid.org/0000-0003-1382-0756

DOI: https://doi.org/10.24919/2413-2039.12/44.32

Бібліографічний опис статті: Філоненко, О., Самойленко, О., Демченко, Н. (2021) Моніторинг проблем організації та проведення педагогічної практики студентів університету. Людинознавчі студіï. Серія «Педагогіка», 12 (44), 207-213, doi: https://doi.org/10.24919/2413-2039.12/44.32

\title{
МОНТТОРИНГ ПРОБЛЕМ ОРГАНІЗАЦІЇ ТА ПРОВЕДЕННЯ ПЕДАГОГІЧНОЇ ПРАКТИКИ СТУДЕНТІВ УНІВЕРСИТЕТУ
}

\begin{abstract}
Анотація. У статті авторами представлено важсливість моніторингу стану організації педагогічної практики як невід 'ємної складової частини системи професійної підготовки майбутнього педагога. Визначається, щуо вивчення чинників, від яких залежить якість організації педагогічних практик, забезпечується об'єктивною інформачією про реальний стан, проблеми та шляхи покращення практичної підготовки студентів. Автори розглядають якість організації та проведення практики студентів, як одне із пріоритетних завдань Ніжинського державного університету імені Миколи Гоголя, визначають види педагогічної практики, характеризують етапи ї̈ проведення.

Авторами здійснено аналіз сучасних наукових досліджень із проблеми удосконалення педагогічної практики. Відзначено, щзо дослідники зосереджені на питаннях активізації взаємодії між закладом вищої освіти і закладами загальної середньої освіти у процесі організації й проведення педагогічної практики студентів, здійснення систематичного контролю за процесом та результатами ї̈ проведення, розвитку інтеграційних механізмів, які забезпечують ефективний взаємозв'язок закладу вищої освіти з роботодавиями.

У статті презентовано результати вивчення стану практичної підготовки студентів, здійсненого Центром акредитачії та лічензування освітньої діяльності, моніторингу якості освіти Ніжинського державного університету імені Миколи Гоголя. Моніторинг ефективності педагогічних практик засвідчує належний рівень їх проходження студентами та дає можливість накреслити першочергові завдання як важливого навчального етапу у формуванні кваліфікованого вчителя. Автори зазначають, щьо головним завданням є удосконалення навчальних планів у частині практичної підготовки та визначають основні позиції, які потребують змін: зміст і форми ознайомчої практики; кількість завдань та обсяги і форми звітності; керівництво із боку викладачів університету.
\end{abstract}

Ключові слова: педагогічна практика, підготовка майбутнього вчителя, моніторинг ефективності педагогічних практик.

Introduction. According to the needs of the time, the socio-pedagogical guidelines of the domestic system of higher pedagogical education is provided for quality professional training of future teachers. The modern school needs specialists who are able to carry out professional activities on a democratic and humanistic basis, to implement educational policy as a priority function of the state, aimed at the development and self-realization of the individual, meeting his educational and spiritual needs. The high quality of training of a modern specialist is ensured by a combination of fundamental and special knowledge with practical training, which is a mandatory component of the educationalprofessional program for obtaining the educational level. Understanding these phenomena encourages scientists to study the problems of organizing pedagogical practice as an integral part of the system of training future teachers.

Analysis of recent publications. Peculiarities of the organization of pedagogical practice of students of higher pedagogical educational establishments are covered in scientific developments of G. Kodzhaspirov, M. Kozii, P. Reshetnikov and others. Methodological aspects of the organization of pedagogical practice, improvement of its semantic and methodological support are expressed by scientific researches of N. Kazakova, S. Kara, L. Katsova, G. Kit, V. Mayboroda, V. Yurchenko. Despite the significant interest of scientists, this problem remains relevant in modern social conditions, as only the monitoring of factors that affect the quality 
of pedagogical practices, provides objective information about the real situation, problems and ways to improve the practical training of students.

The purpose of the article is to study the state of practical training of university students, to outline the problems that need to be solved, to outline the priority tasks of improving pedagogical practice as an important educational stage in the formation of a qualified teacher.

Presentation of the main material. The formation of stable professional skills in the field of organization of the educational process and thus providing a practical component in the pedagogical competence of the graduate is the goal of pedagogical practice of students of Nizhyn Mykola Gogol State University. Among the priority tasks of the university is to ensure the quality of organization and practice of students. Pedagogical practice is carried out in accordance with educational and professional programs for obtaining educational bachelor and master levels, regulations of the Ministry of Education and Science of Ukraine, industry standards. During its passage, students study modern forms, methods, techniques and means of educational work. They organize various educational stages, using general didactic, psychological, methodological and subject mechanisms, knowledge of the specialty.

Types of practice in each specialty, their duration and timing are determined by the curriculum. Depending on the specific didactic goals, the pedagogical practice of bachelors has the following forms:

- introductory practice (first year);

- propaedeutic practice (second year);

- educational practice in children's health and recreation facilities (third year);

- pedagogical practice in secondary school (IV year) (Kovalenko et al., 2010).

In Mykola Gogol State University pedagogical practice is carried out in three stages. The first stageintroduction and propaedeutic practices are passive. Students get acquainted with the system of work of the educational institution and with the specifics of the organization of the educational process at school. Introduction practice takes place during the study of the theoretical course «Introduction to the specialty» without separation from study. Propaedeutic practice lasts from one to two weeks, takes place in the second year with a break from training.

The second stage of pedagogical practice is educational practice with a Docent, which is held in the third year of study, its duration is four weeks, it takes place in summer health and recreation facilities for children. The purpose of educational practice is to gain experience in independent organization of life and activities of the children's team, in particular during the summer holidays; formation of skills and abilities to combine collective, group and individual forms of work; improvement of organizational, communicative, creative skills of the future teacher; preparation for the performance of educational functions (Filonenko, 2020).

The most significant in the acquisition of professional competencies is the third stage of pedagogical practice - pedagogical (production) practice in the fourth year. During pedagogical (industrial) practice students master modern methods and forms of organization of the educational process in secondary school, professional skills and abilities for making independent decisions during specific activities in real conditions are formed on the basis of knowledge obtained at the university; the needs of systematic updating of the knowledge and their creative application in practical activity are brought up; the initial level of pedagogical skill of the teacher is formed (Kovalenko et al., 2018).

The time of pedagogical (production) practice can be divided into four stages: introduction, planning, implementation and final. The duration of the introduction stage depends on the individual psychological characteristics of students, professional and pedagogical training, the attitude of the school administration and teachers to pedagogical practice in general and to students in particular. The success of pedagogical practice depends primarily on the friendly atmosphere and mutual understanding between trainees and school staff, a clear organization of practical activities of students and teachers, mutual assistance between them. Students on the first day of pedagogical practice get acquainted with the secondary school, get acquainted with the students assigned to them by the class, with the class teacher, get acquainted with the content and methods of teaching and educational work in the assigned class (Dudnyk, 2017).

At the planning stage, students, depending on the tasks of pedagogical practice, plan their further work (choosing a student to write a psychological and pedagogical characteristics, drawing up a work plan for the coming weeks, choosing a lesson topic and educational event, preparation for them, etc. At this stage, students One of the effective ways to improve pedagogical practice is a clear, well-designed plan, which allows both students and teachers to organize their own working time well and use it usefully. Will guide 
students' practice, are important factors in the practical training of future teachers. The better the teacher is trained, the more problematic issues that arise in students during practice, will be solved (Ivanova, 2014).

At the stage of implementation, students perform the functions of subject teacher and class teacher, perform the tasks assigned to them, taking an active part in the life of the student body. The last days of pedagogical practice and the first days after its end are called the final stage. At this time, students draw up reporting documents and undergo internship defense. Positive results of pedagogical practice depend on: the level of preparedness of students both theoretically and psychologically; successful selection of techniques, methods of working with students and staff; choice of educational institution; methodical level and skill of teachers (Dudnyk, 2017).

The opinion of scientists V. Proskunin and O. Babenko is important that the intensification of interaction between higher and general educational institutions in the process of organizing and conducting pedagogical practice of students gives an opportunity to comprehensively influence the formation and development of future teachers (Proskunin, \& Babenko, 2014).

Among the organizational and methodological conditions that ensure the effective formation of future teachers S. Kara determines the improvement of the process of organizing pedagogical practice:

1) improving the content of students' activities during pedagogical practice;

2) organization of coordinated work of all heads of practice (teachers of higher educational institution and school teachers);

3) compliance with the uniform requirements of practice leaders to assess the practical activities of the student;

4) determination of ways of harmonious entry of students into professional activity at each stage of pedagogical practice (Kara, 2013).

V. Choni and N. Skobelska call the implementation of systematic control over the process and results of its implementation a significant condition for improving the organization of production practice, which allows to identify existing shortcomings in the educational process and increases the responsibility for each task (Choni, \& Skobelska, 2015).

We support O. Luhivska's opinion that modernization of the process of organization of industrial practice should provide for further development of integration mechanisms that ensure effective interaction of higher education with employers on the following issues: terms of employment of graduates, level of remuneration, assessment of new employee readiness. Systematic cooperation with employers during the internship, extensive use of experience in creating on the basis of higher education institutions and enterprises centers of practical training, promote the organization of practical training, provide integration in the system of higher school in the direction of training, increase research efficiency etc. (Luhivska, 2015).

In order to investigate the problem of the importance of continuous pedagogical practice in the training of future teachers, the Center of Educational Quality at Nizhyn Mykola Gogol State University in the 2019-2020 academic year conducted a sociological survey of 100 fourth-year students who passed pedagogical practice. Among them: 47 students of the Faculty of Philology, 15 - Educational and Scientific Institute of Exact Sciences and Economics, 38 - Historical and Legal.

The students were asked: "How important was it for you personally to go through the stages of continuous pedagogical practice?” (see Table 1).

Table 1

Distribution of students' answers

\begin{tabular}{|c|c|c|c|c|}
\hline Type of practice & Very important & $\begin{array}{c}\text { More important } \\
\text { than no }\end{array}$ & $\begin{array}{l}\text { More less } \\
\text { important }\end{array}$ & Not important \\
\hline Introduction (I year) & \multicolumn{2}{|c|}{$45 \%$} & \multicolumn{2}{|c|}{$55 \%$} \\
\hline Propaedeutic (II year) & \multicolumn{2}{|c|}{$77 \%$} & \multicolumn{2}{|c|}{$23 \%$} \\
\hline Educational with Docent (III year) & \multicolumn{2}{|c|}{$92 \%$} & \multicolumn{2}{|c|}{$8 \%$} \\
\hline Pedagogical (IV) курс & \multicolumn{2}{|c|}{$93 \%$} & \multicolumn{2}{|c|}{$7 \%$} \\
\hline
\end{tabular}

Apart from the «introduction» practice in the first year, all other stages are defined as important.

There were quite interesting answers to the question: "What do you think should be the duration of each stage of pedagogical practice?” (\%) (see Table 2) 
Table 2

Distribution of students answers

\begin{tabular}{|l|c|c|c|}
\hline \multicolumn{1}{|c|}{ Types of practicies } & Like proposed & More than proposed & Less than proposed \\
\hline Introduction (I year) & $58 \%$ & $32 \%$ & $10 \%$ \\
\hline Propaedeutic (II year) & $68 \%$ & $25 \%$ & $7 \%$ \\
\hline Educational with Docent (III year) & $65 \%$ & $23 \%$ & $12 \%$ \\
\hline Pedagogical (IV year) & $52 \%$ & $38 \%$ & $10 \%$ \\
\hline
\end{tabular}

Most students agree with the proposed terms of practice.

To complete successfully the practice it is necessary to have appropriate knowledge and skills in professional methods, pedagogy and psychology. Respondents' answers to the question: "Did you have enough knowledge and skills to pass pedagogical practice in the fourth year?" (\%) give reason to believe that students of Nizhyn Mykola Gogol State University are ready for practice (see Table 3).

Distribution of students answers

\begin{tabular}{|l|c|c|c|c|}
\hline \multicolumn{1}{|c|}{ Discipline } & Enough & $\begin{array}{c}\text { More enough } \\
\text { than not }\end{array}$ & $\begin{array}{c}\text { Not that } \\
\text { enough }\end{array}$ & $\begin{array}{c}\text { Not enough } \\
\text { at all }\end{array}$ \\
\hline In professional methodologies & $90(88) \%$ & $10(12) \%$ & & \\
\hline In pedagogics & $88(89) \%$ & $12(11) \%$ & & \\
\hline In psychology & $87(85) \%$ & $13(15) \%$ & & \\
\hline
\end{tabular}

Note. In brackets a quantitative distribution of the answers to this question of students who connect their future with the teaching profession is provided. (\%)

Also in the process of the survey we were interested in the question: How has your idea of the teaching profession changed after the internship? (\%)

The perception of the teaching profession The perception of $42 \%$ of students became more positive after the internship; in 37\% - has not changed; in $21 \%$ - became more negative.

The results of sociological research allow us to conclude that pedagogical practice contributes to the formation of a positive attitude to the teaching profession, especially among those students who have chosen this profession.

Monitoring the effectiveness of educational practices shows the appropriate level of their passage by students. The results of the survey showed:

1. Slightly more than $25 \%$ of respondents consider the profession of a teacher to be their vocation and the main goal of employment, despite the fact that almost all respondents $(88.8 \%)$ state that NDU provides proper training for future teachers.

2. Of all the faculties, philology is the most work-oriented in school $-39 \%$ of students define the teaching profession as the main and priority. The least research-oriented institute of exact sciences and economics is $15 \%$.

3. The content and forms of introductory practice, which almost $55 \%$ of the surveyed students consider unimportant, need to be seriously adjusted.

4. Almost a third of students $(30.5 \%)$ tend to increase the duration of pedagogical practice (this question requires more detailed study to determine the motives of this answer: whether there is a desire to further test the knowledge and skills acquired at the university, or such a position due to overload students with a large number of tasks in practice).

5. In general, students had enough knowledge acquired at the university for successful internship (more than $80 \%$ in all disciplines), however, $10-15 \%$ of respondents say that they lacked knowledge of professional methods, pedagogy and psychology.

6. Practice promotes the formation of a positive attitude to the teaching profession (after its implementation in $42.7 \%$ of surveyed students, the attitude to the teaching profession has become more positive).

7. The survey showed a high degree of formalization of pedagogical practice and the transfer of emphasis from creative work to document making. In particular, if conducting lessons was difficult for $35 \%$ of students, and establishing contacts with students - for $11 \%$ of respondents, the difficulty of preparing reports was recognized by $70 \%$ of respondents. In our opinion, this requires adjustment of both the number of tasks in pedagogical practice and the forms of reporting. 
8. Pedagogical practice allowed students to increase self-esteem, acquisition of competencies, which ranges from 7.6 to 8.7 on a 10 -point scale.

9. The success of students according to the results of pedagogical practice is high: excellent $40 \%$; good $-34 \%$; satisfactory $-26 \%$, it means the quality is $-74 \%$.

Conclusions. The study provides an opportunity to identify the main positions that need to be changed: the content and forms of introductory practice; duration of pedagogical practice; the number of tasks given to students in pedagogical practice, the scope and forms of reporting; hours for the management of pedagogical practice should not be a "reload" of teachers, without taking into account the experience of work in educational institutions; Insufficient methodological assistance and control by university teachers, caused by the load of classroom work at the university according to the schedule.

It should be pointed that according to the draft Concept for the development of pedagogical education in Ukraine, a mandatory component of the educational process of training higher education in the pedagogical profession is continuous pedagogical practice. To accomplish this key task, the amount of practical training must be at least 30 ECTS credits within the compulsory part of the bachelor's program and at least 30 credits (including the master's study) within the compulsory part of the master's program (Nakaz Ministerstva osvity i nauky Ukrainy, 2018). To date, the share of practical training of higher education students in the bachelor's degree is 18-24 credits, and in master's programs this share together with the preparation of master's research -24 credits. Therefore, the priority of the future is to improve curricula in terms of practical training.

\section{BIBLIOFRAPHY}

1. Дудник Н. Роль педагогічної практики у формуванні професійних компетентностей майбутнього вчителя. Проблеми підготовки сучасного вчителя. 2017. № 16. С. 129-135.

2. Іванова Ю.М. Шляхи удосконалення педагогічної практики в науковій літературі. Вісник Глухівського національного педагогічного університету імені Олександра Довженка. Сер. : Педагогічні науки. 2014. Вип. 24. С. 34-41. URL : http://nbuv.gov.ua/UJRN/vgnpu_2014_24_8.

3. Кара С.I. Удосконалення процесу організації педагогічної практики - пріоритетна умова формування професійної компетентності майбутніх учителів основ здоров'я. Педагогіка, психологія та медико-біологічні проблеми фізичного виховання і спорту. 2013. № 11. С. 28-31. doi:10.6084/m9.figshare.815870.

4. Лугівська О.П. Напрями модернізації процесу організації виробничої практики студентів. Якість вищої освіти: вдосконалення змісту та організаиії практичної підготовки студентів : матеріали XL Міжнародної науково-методичної конференції 25-26 лютого 2015 року. Полтава : ПУЕТ, 2015. 398 с.

5. Методичні рекомендації з організації педагогічної практики для студентів IV курсу / Є.I. Коваленко, Л.О. Дубровська, О.С. Філоненко, О.В. Самойленко, Н.О. Падун. Ніжин : Видавництво НДУ імені Миколи Гоголя, 2018. $74 \mathrm{c}$.

6. Наказ Міністерства освіти і науки України «Про затвердження Концепції розвитку педагогічної освіти» від 16.07.2018 p. № 776/ URL : http://oipopp.ed-sp.net/public/attached_files/5b7bb2dcc424a809787929.pdf.

7. Організація педагогічної практики студентів Ніжинського державного університету імені Миколи Гоголя : інструктивно-методичні матеріали / укл. : Є.І. Коваленко, О.С. Філоненко, Н.М. Стрельнікова, Н.О. Падун, Н.І. Бєлкіна. Ніжин: Видавництво НДУ імені Миколи Гоголя, 2010. 39 с.

8. Проскунін В., Бабенко О. Деякі аспекти змісту й організації педагогічної практики студентів в умовах неперервної педагогічної освіти. Рідна школа. 2014. №3 (березень). С. 24-28.

9. Філоненко О.С. Виховна практика студентів у дитячих закладах оздоровлення та відпочинку - організація та проведення: методичні рекомендації. Ніжин : НДУ ім. М. Гоголя, 2020. 52 с.

10. Чоні І.В., Скобельська Н.В. Удосконалення змісту та організації виробничої практики. Якість вищої освіти: вдосконалення змісту та організаиії практичної підготовки студентів : матеріали XL Міжнародної науково-методичної конференції 25-26 лютого 2015 року. Полтава : ПУЕТ, 2015. 398 с.

\section{REFERENCES}

1. Dudnyk N. (2017). Rol pedahohichnoi praktyky u formuvanni profesiinykh kompetentnostei maibutnoho vchytelia. [The role of pedagogical practice in the formation of future teachers' professional competence]. Problemy pidhotovky suchasnoho vchytelia. № 16, 129-135. [in Ukrainian]

2. Ivanova Yu.M. (2014). Shliakhy udoskonalennia pedahohichnoi praktyky v naukovii literaturi. [Ways of improving teaching practice in the scientific literature]. Visnyk Hlukhivskoho natsionalnoho pedahohichnoho universytetu imeni Oleksandra Dovzhenka. Ser. : Pedahohichni nauky. Vyp. 24, 34-41. URL: http://nbuv.gov.ua/ UJRN/vgnpu_2014_24_8. [in Ukrainian] 
3. Kara S.I. (2013). Udoskonalennia protsesu orhanizatsii pedahohichnoi praktyky - priorytetna umova formuvannia profesiinoi kompetentnosti maibutnikh uchyteliv osnov zdorovia. [An improvement of process of organization of pedagogical practice is priority condition of forming of professional competence of future teachers the basics of health]. Pedahohika, psykholohiia ta medyko-biolohichni problemy fizychnoho vykhovannia $i$ sportu. № 11, 28-31. doi:10.6084/m9.figshare.815870. [in Ukrainian]

4. Luhivska O.P. (2015). Napriamy modernizatsii protsesu orhanizatsii vyrobnychoi praktyky studentiv. [Directions of modernization of the organization process of students ' practical training]. Yakist vyshchoi osvity: vdoskonalennia zmistu ta orhanizatsii praktychnoi pidhotovky studentiv : materialy XL Mizhnarodnoi naukovometodychnoi konferentsii 25-26 liutoho 2015 roku. Poltava : PUET, 398. [in Ukrainian]

5. Kovalenko Ye.I., Dubrovska L.O., Filonenko O.S., Samoilenko O.V., \& Padun N.O. (2018). Metodychni rekomendatsii z orhanizatsii pedahohichnoi praktyky dlia studentiv IV kursu [Workbook on the organization of teaching practice for fourth-year students]. Nizhyn : Vydavnytstvo NDU imeni Mykoly Hoholia, 74 s. [in Ukrainian]

6. Nakaz Ministerstva osvity i nauky Ukrainy «Pro zatverdzhennia Kontseptsii rozvytku pedahohichnoi osvity» vid 16.07.2018 r. № 776. [Order of the Ministry of Education and Science of Ukraine 'On approving the Concept of the teacher education development' dated 16.07.2018 № 776]. URL: http://oipopp.ed-sp.net/public/attached_ files/5b7bb2dcc424a809787929.pdf. [in Ukrainian]

7. Kovalenko Ye.I., Filonenko O.S., N.M. Strielnikova, Padun N.O., N.I. Bielkina. (2010). Orhanizatsiia pedahohichnoi praktyky studentiv Nizhynskoho derzhavnoho universytetu imeni Mykoly Hoholia : instruktyvnometodychni materialy. [Organization of students` teaching practice at Nizhyn Mykola Gogol State University: guidance materials]. Nizhyn : Vydavnytstvo NDU imeni Mykoly Hoholia, 39. [in Ukrainian]

8. Proskunin V., \& Babenko O. (2014). Deiaki aspekty zmistu y orhanizatsii pedahohichnoi praktyky studentiv $\mathrm{v}$ umovakh neperervnoi pedahohichnoi osvity. [Some aspects of content and organization of students' pedagogical practice at constant studying]. Ridna shkola. № 3 (berezen), 24-28. [in Ukrainian]

9. Filonenko O.S. (2020). Vykhovna praktyka studentiv u dytiachykh zakladakh ozdorovlennia ta vidpochynkuorhanizatsiia ta provedennia: metodychni rekomendatsii. [Students' tutor experience in child health and recreation centres - organization and conduct: workbook]. Nizhyn : NDU im. M. Hoholia, 52. [in Ukrainian]

10. Choni I.V., \& Skobelska N.V. (2015). Udoskonalennia zmistu ta orhanizatsii vyrobnychoi praktyky. [The improvement of the content and organization of practical training]. Yakist vyshchoi osvity: vdoskonalennia zmistu ta orhanizatsii praktychnoi pidhotovky studentiv : materialy XL Mizhnarodnoi naukovo-metodychnoi konferentsii 25-26 liutoho 2015 roku. Poltava : PUET, 398. [in Ukrainian]

Стаття надійшла до редакиії 25.05.2021 